\title{
Microencapsulation of Lactobacillus sp. Using two Different Materials and Comparison for Encapsulation Efficiency
}

\author{
V. Padhmavathi and Radhakrishnan Preetha* \\ Department of Food Process Engineering, SRM University, Kattankulathur - 603203, India. \\ http://dx.doi.org/10.13005/bbra/2148
}

(Received: 09 March 2016; accepted: 20 April 2016)

\begin{abstract}
Probiotics are microorganisms which, when taken orally, provide beneficial effects on human gut health. Microencapsulation of probiotics is a technique that is currently receiving considerable interest as it helps probiotics to survive against adverse environmental conditions in the human body. In this project, a study to determine the stronger encapsulating material is done by encapsulating Lactobacillus sp. using alginate and skim milk alginate. The encapsulation was done by extruding into $100 \mathrm{mM} \mathrm{CaCl}_{2}$ solution. Viability test, bile salt tolerance test and storage stability was performed. On analyzing the results it was found that, the skim milk alginate beads had the efficiency of $96.48 \%$. The bacteria encapsulated using skim milk alginate was more viable and more tolerant towards bile salt. The storage stability test was carried out for a period of 28 days and it was found that the probiotic encapsulated using skim milk alginate were more viable. From the results it was concluded that skim milk alginate was a stronger encapsulating material than alginate because of the strong network forming nature of milk proteins.
\end{abstract}

Keywords: Probiotics, Lactobacillus sp.,microencapsulation, alginate, skim milk.

Probiotics are defined as "Live microorganisms which when administered in adequate amounts confer a health benefit on the

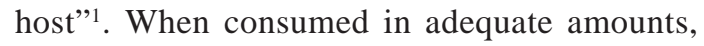
probiotics are live microorganisms that provide a health benefit to the host ${ }^{2}$. Interest in the consumption of probiotic food products is increasing and a many functional foods have been developed $^{3}$. They confer many health benefits such as suppressing growth of pathogens, preventing diarrhoea, constipation, and food allergies, synthesizing nutrients and enhancing their bioavailability, and anti-neoplastic activity ${ }^{4}$, ${ }^{5}$. The survivability of the probiotics is to be

\footnotetext{
* To whom all correspondence should be addressed. Tel.: 9176610351;

E-mail: preetha.r@ktr.srmuniv.ac.in
}

maintained during manufacture, storage, and delivery to gastrointestinal tract to provide their health benefit ${ }^{3}$. The most common probioticcontaining foods are fermented dairy products that contain lactic acid bacteria (LAB). Probiotics are highly stable in dairy products than in non-dairy products. Various solutions to this problem, such as durable strain selection in adverse environments ${ }^{6}$ and addition of prebiotics ${ }^{7}$ have been evaluated.

Encapsulation has been investigated for protecting probiotics in gastrointestinal tract ${ }^{8}$. The advantages of encapsulation are prevention of interfacial inactivation, stimulation of production and excretion of secondary metabolites, and continuous utilization. During fermentation it also enhances microbial survival and operating efficiency $^{9}$. Severalstudies have shown successful microencapsulation and coating ofbacteria using various encapsulating materials and methods ${ }^{10-14}$. 
A process in which the cells are retainedwithin an encapsulating matrix or membrane is known as microencapsulation.

Extrusion technique of microencapsulation has been used exclusively for encapsulating volatile and unstable ûavors in glassy carbohydrate matrices and probiotic microorganisms $\mathrm{s}^{15-21}$. The main advantage of this process is that, the matrix is strong enough and protects the microbes in very low $\mathrm{pH}$ conditions too.

Alginates are natural anionic polysaccharides made up of D-mannuronic and Lguluronic acid residues ${ }^{22}$. Alginate, a polymer extracted from seaweed, is a commonly usedencapsulation agent because it is non-toxic, biocompatible,and inexpensive. The additional benefits of using alginate is the ease of solubilizing alginategel (by $\mathrm{Ca}++$ sequestration) and its release of entrapped cellswithin the human intestine ${ }^{23,24}$. There are few studies on the effect of whey protein and skim milk powder on encapsulation efficiency of probiotic microorganisms ${ }^{25}$. Milk proteins have good immobilization properties.

Strains of Lactobacillus and Bifidobacterium species, which are lactic acid bacteria, are the most common microbes employed as probiotics. Other species considered as probiotic may include lactococci, some enterococci and some streptococci. Curd and other dairy products are a very good source for Lactobacillus species.

\section{MATERIALSAND METHODS}

\section{Subculturing and maintenance}

The probiotic organism,Lactobacillus $s p$, was obtained from MTCC, Chandigarh. The lyophilised powder was sub-cultured by inoculating into MRS broth and incubating at $37^{\circ} \mathrm{C}$ for 24 hours. After 24hours, the culture from the broth was further sub-cultured by streak plating onto MRS agar and incubated for 24 hours at $37^{\circ} \mathrm{C}$. These plates were then stored at $4^{\circ} \mathrm{C}$ for a period of one month before sub-culturing again.

\section{Microencapsulation of probiotic}

Microencapsulation of the organism was done using two materials mentioned below by extrusion technique.

\section{Alginate}

Alginate solution was sterilised at $121^{\circ} \mathrm{Cfor} 15 \mathrm{~min} .14 \mathrm{ml}$ sodium alginate was added to a beaker. $1 \mathrm{ml}$ culture was added to the beaker. This mixture was extruded in $100 \mathrm{mM} \mathrm{CaCl}_{2}$ solution and stirred for $30 \mathrm{~min}$ at $100 \mathrm{rpm}$. The beads obtained were washed with distilled water and sealed in sterile conical flasks.

\section{Skim milk-alginate}

Alginate solution was sterilised at $121^{\circ} \mathrm{C}$ for $15 \mathrm{~min}$. Skim milk was sterilised at $110^{\circ} \mathrm{C}$ for $15 \mathrm{~min}$. $13 \mathrm{ml}$ sodium alginate was added to a beaker along with $6 \mathrm{ml}$ skim milk. $1 \mathrm{ml}$ culture was added to the beaker. This mixture was extruded in $100 \mathrm{mM} \mathrm{CaCl}_{2}$ solution and stirred for $30 \mathrm{~min}$. The beads obtained were washed with distilled water and sealed in sterile conical flasks.

\section{Encapsulation efficiency}

The microencapsulated bacterial samplewas solubilized in sodium citrate solution. The sample was serially diluted upto 10 fold and plated onto MRS agar by spread plating. It was incubated at $37^{\circ} \mathrm{C}$ for 24 hours. Number of colonies were counted and the encapsulation efficiency (EE) was calculated as described by ${ }^{26}$.

$\mathrm{EE}=\mathrm{N} / \mathrm{No} \times 100$

Where, $\mathrm{N}$ - Number of colonies from beads

No- Number of colonies from free cell suspension.

Bile salt tolerance test of free and encapsulated probiotic

Free cell suspension $(0.5 \mathrm{ml})$ was added to $4.5 \mathrm{ml}$ of bile salt solution (2\%) and kept at $37^{\circ} \mathrm{C}$ for 1 hour and 2 hours. Solution from each flask was then serially diluted upto 10 fold using saline solution. $1 \mathrm{ml}$ from last test tube was plated onto MRS agar plates by spread plate method. These plates were incubated at $37^{\circ} \mathrm{C}$ for 24 hours and number of colonies were counted.

$0.5 \mathrm{~g}$ beads were added to $4.5 \mathrm{ml}$ of bile salt solution (2\%) and kept at $37^{\circ} \mathrm{C}$ for 1 hour and 2 hours. The capsules were removed from bile salt solution at specified time intervals and added to $4.5 \mathrm{ml}$ of sodium citrate solution to be solubilised. Once released completely these solutions were serially diluted upto 10 fold using saline solution. $1 \mathrm{ml}$ from last test tube was plated onto MRS agar plates by spread plate method. These plates were incubated at $37^{\circ} \mathrm{C}$ for 24 hours and number of colonies were counted. 


\section{Storage stability of free and encapsulated cells}

Encapsulated beads and free cell suspension are stored at $4^{\circ} \mathrm{C}$ for a period of 1 month.At regular intervals such as $1,3,5,7,14,21$, 28 days the encapsulated cultures were revived by using sodium citrate solution and serially diluted. These were then plated onto MRS agar. While, the free cells were serially diluted upto 10 fold and plated onto MRS agar. The colonies were counted to determine the survivability.

\section{Statistical analysis}

All the experiments were repeatedthree times. The data was subjected to analysis of variance (ANOVA) and the significance of difference between means was determined by Duncan's multiple range tests ( $\mathrm{p}<0.05$ ). The results were presented in mean value \pm standard deviation (SD).

\section{RESULTSAND DISCUSSION}

\section{Size and Encapsulation efficiency}

Extrusion method is the most commonly used method for encapsulating probiotic.In extrusion method the size and encapsulation yield of microspheres is affected by several factors such as nozzle size, polymer concentration and composition [27]. Their results showed thatdiameters of alginate milk microspheres, prepared using nozzle 0.45 and $0.20 \mathrm{~mm}$ were $830 \pm$ 10 and $381 \pm 8 \mu \mathrm{m}$ (ûgures not shown), respectively.The size of microspheres should be below $100 \mu \mathrm{m}$ to avoid negative sensory impact in food products [28]. Due to the limitation of nozzle size (minimum nozzle size provided was $0.20 \mathrm{~mm}$ ) ,the minimum size of microspheres obtained by Voo et al., 2011 was around $381 \pm 8 \mu \mathrm{m}$.

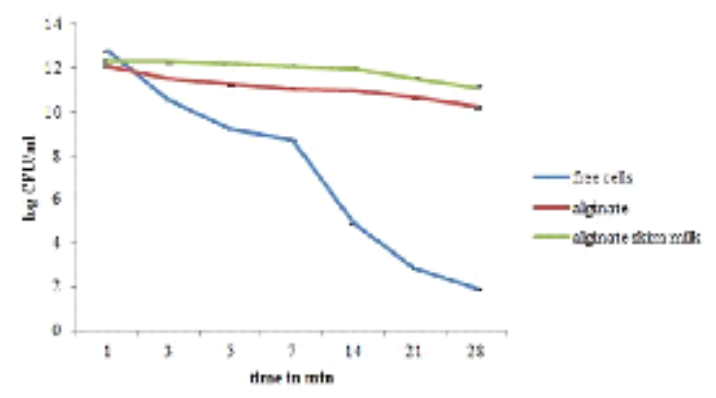

Fig. 1. Storage stability of free and encapsulated cells
In this study it was seen that polymer composition influenced the slight variation in diameter of microspheres. Alginate and skim milk alginate were the two different compositions used. The microspheres were prepared with a $0.20 \mathrm{~mm}$ nozzle. Alginate microspheres had a diameter of $321 \pm 10 \mu \mathrm{m}$ and skim milk alginate microspheres had a diameter of $367 \pm 6 \mu \mathrm{m}$.

Studies show that high encapsulation efficiency (close to 100\%) were easily obtained through extrusion method [29,30]. In the present study, $94.44 \%$ efficiency was obtained when alginate was used as encapsulating material. On the other hand, a significantly different $(\mathrm{p}<0.05)$ efficiency of $96.48 \%$ was obtained when skim milk alginate was used. The encapsulation efficiency of skim milk-alginate was higher than that of alginate.

Bile salt tolerance of free and encapsulated cells In this study, as result of action of bile salts , there was deterioration in cell wall intergrity and free Lactobacillus $s p$ totally lost its viability in bile salt. Many references mentioned probiotics were sensitive to bile salt solution. There are observations that a decrease of $5 \log \mathrm{CFU} / \mathrm{ml}$ in viable cell counts of Biûdobacterium adolescentis (B. adolescentis) occurs in $2 \%$ bile salt solution at $37 \mathrm{C}$ after $12 \mathrm{~h}$ incubation ${ }^{31}$. It has been found that B.adolescentis reduced by about $2 \log \mathrm{CFU} / \mathrm{mL}$ after $2 \mathrm{~h}$ incubation in $0.5 \%$ bile salt at $37 \mathrm{C}^{28}$. However, the results shown in Table 1 clearly indicate that encapsulated microspheres could provide a good protection against the damage of the bile salt solution compared to free Lactobacillus $s p$ cells and there was a significant difference $(\mathrm{p}<0.05)$ in the results.

Different researchers have used different concentrations and sources of bile salts. So,

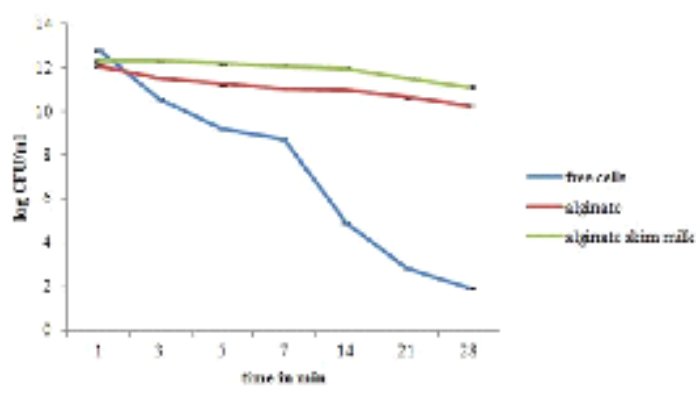


making a comparison was difficult. It was also found that encapsulated probiotic bacteria could survived better than free probiotic cells in 1-3\% bile salts solution ${ }^{32,26}$.

\section{Storage stability of free and encapsulated cells}

In the present study it was seen that the number of viable cells reduced drastically when left without encapsulation. Encapsulated cells were protected and hence the cells were viable and survived a storage period of 28 days. Special treatments, suchas coating of beads with polymers, blending with other polymers,improves the storage stability of probiotic ${ }^{33}$. The protective effectby whey protein encapsulation was evaluated at 5C on storing for 180 days ${ }^{34}$. Fig 1, below, clearly indicates that microencapsulation using skim milk alginate, improved the viability of cells on storage.

\section{CONCLUSION}

Lactobacillus sp. was successfully encapsulated in alginate and skim milk- alginate microspheres prepared by extrusion method. The cells of Lactobacillus sp.encapsulated in microspheres showed better survival ability than that of free cells in high bile salt concentrations (2.0\%) and long time storage (28 days). It was also found that skim milk-alginate was a stronger material when compared to alginate as all results indicated more viability in skim milk- alginate microspheres. Encapsulation has once again proved to be a good method to protect probiotics in gastrointestinal environments. Skim milkalginate microspheres show the potential as a new encapsulating material for preserving the viability of probiotics during oral administration. Further studies are to be carried out in gastro-intestinal environments.

\section{ACKNOWLEDGEMENT}

We express our thanks to Prof. C. Muthamizchelvan, Director, Engineering Technology and Dr. M. Vairamani, Dean School of Bioengineering, SRM University and Dr. K. A. Athmaselvi, Head of the department, Department of Food Process Engineering, for their help and encouragement.

\section{REFERENCES}

1. Joint FAO/WHO Working Group. Guidelines for the evaluation of probiotics in food. London: World Health Organization, ON, Canada: Food and Agriculture Organization. 2002.

2. Saarela M, Lähteenmäki L, Crittenden R, Salminen S, Mattila-Sandholm T. Gut bacteria and health foods - the European perspective. International journal of food microbiology. 2002;78(1):99-117.

3. Ying DY, Phoon MC, Sanguansri L, Weerakkody R, Burgar I, Augustin MA. Microencapsulated Lactobacillus rhamnosus GG powders: relationship of powder physical properties to probiotic survival during storage. Journal of Food Science. 2010 ;75(9):E588-95.

4. Rafter J. Probiotics and colon cancer. Best Practice \& Research Clinical Gastroenterology. 2003; 17(5):849-59.

5. Salminen S, von Wright A, Morelli L, Marteau P, Brassart D, de Vos WM, Fondén R, Saxelin M, Collins K, Mogensen G, Birkeland SE. Demonstration of safety of probiotics-a review. International journal of food microbiology. 1998; 44(1):93-106.

6. Chou LS, Weimer B. Isolation and characterization of acid-and bile-tolerant isolates from strains of Lactobacillus acidophilus. Journal of Dairy Science. 1999; 82(1):23-31.

7. Topping DL, Fukushima M, Bird AR. Resistant starch as a prebiotic and synbiotic: state of the art. Proceedings of the Nutrition Society. 2003; 62(01):171-6.

8. Favaro-Trindade CS, Grosso CR Microencapsulation of L. acidophilus (La-05) and $\mathrm{B}$. lactis (Bb-12) and evaluation of their survival at the $\mathrm{pH}$ values of the stomach and in bile. Journal of microencapsulation. 2002 ; 19(4):485-94.

9. Champagne CP, Lacroix C, Sodini-Gallot I. Immobilized cell technologies for the dairy industry. Critical Reviews in Biotechnology. 1994; 14(2):109-34.

10. Annan NT, Borza A, Moreau DL, Allan-Wojtas PM, Hansen LT. Effect of process variables on particle size and viability of Bifidobacterium lactis Bb-12 in genipin-gelatin microspheres. Journal of microencapsulation. 2007 ; 24(2):15262.

11. Jankowski T, Zielinska M, Wysakowska A. Encapsulation of lactic acid bacteria with alginate/starch capsules. Biotechnology Techniques. 1997; 11(1):31-4. 
12. Kebary KM, Hussein SA, Badawi RM. Improving viability of bifidobacterium and their effect on frozen ice milk.

13. Khalil AH, Mansour EH. Alginate encapsulated bifidobacteria survival in mayonnaise. Journal of Food Science. 1998; 63(4):702-5.

14. Lee KY, Heo TR. Survival of Bifidobacterium longumImmobilized in Calcium Alginate Beads in Simulated Gastric Juices and Bile Salt Solution. Applied and Environmental Microbiology. 2000; 66(2):869-73.

15. Benczedi D, Blake A. Encapsulation and the controlled release of flavours. Leatherhead Food RA Food Industry Journal. 1999; 2:36-48.

16. Benczedi D, Bouquerand PE. Process for the preparation of granules for the controlled release of volatile compounds. PCT WO. 2001; 1(17372):A1.

17. Blake A. Flavor encapsulation with carbohydrate glasses. International Food Ingredient. 1994; 3:30-4.

18. Gunning YM, Gunning PA, Kemsley EK, Parker R, Ring SG, Wilson RH, Blake A. Factors affecting the release of flavor encapsulated in carbohydrate matrixes. Journal of agricultural and food chemistry. 1999 ; 47(12):5198-205.

19. Qi ZH, Xu A. Starch-based ingredients for flavor encapsulation. Cereal Foods World. 1999.

20. Reineccius GA. Carbohydrates for flavor encapsulation. Food Technology. 1991; 45(3):144-6.

21. Saleeb FZ, Pickup JG, inventors; General Foods Corporation, assignee. Fixation of volatiles in extruded glass substrates. United States patent US 4,820,534. 1989 Apr 11.

22. Thu B, Bruheim P, Espevik T, Smidsrød O, SoonShiong P, Skjåk-Bræk G. Alginate polycation microcapsules: I. Interaction between alginate and polycation. Biomaterials. 1996; 17(10):1031-40.

23. Adhikari K, Mustapha A, Grün IU. Survival and metabolic activity of microencapsulated Bifidobacterium longum in stirred yogurt. Journal of Food Science. 2003; 68(1):275-80.

24. Sultana K, Godward G, Reynolds N, Arumugaswamy R, Peiris P, Kailasapathy K. Encapsulation of probiotic bacteria with alginate-starch and evaluation of survival in simulated gastrointestinal conditions and in yoghurt. International journal of food microbiology. 2000; 62(1):47-55.
25. Andic SE, Zorba O, Tuncturk Y. Effect of whey powder, skim milk powder and their combination on yield and textural properties of meat patties. International Journal Agricultural Biology. 2010; 1:871-6.

26. Kailasapathy K. Survival of free and encapsulated probiotic bacteria and their effect on the sensory properties of yoghurt. LWT-Food Science and Technology. 2006; 39(10):1221-7.

27. Voo WP, Ravindra P, Tey BT, Chan ES. Comparison of alginate and pectin based beads for production of poultry probiotic cells. Journal of bioscience and bioengineering. 2011; 111(3):294-9.

28. Hansen LT, Allan-Wojtas PM, Jin YL, Paulson AT. Survival of Ca-alginate microencapsulated Bifidobacterium spp. in milk and simulated gastrointestinal conditions. Food Microbiology. 2002; 19(1):35-45.

29. Ma Y, Pacan JC, Wang Q, Xu Y, Huang X, Korenevsky A, Sabour PM. Microencapsulation of bacteriophage felix O1 into chitosan-alginate microspheres for oral delivery. Applied and environmental microbiology. 2008 ; 74(15):4799-805.

30. Ma Y, Pacan JC, Wang Q, Sabour PM, Huang X, $\mathrm{Xu}$ Y. Enhanced alginate microspheres as means of oral delivery of bacteriophage for reducing Staphylococcus aureus intestinal carriage. Food hydrocolloids. 2012 ; 26(2):434-40.

31. Kailasapathy K, Chin J. Survival and therapeutic potential of probiotic organisms with reference to Lactobacillus acidophilus and Bifidobacterium spp. Immunology and Cell Biology. 2000; 78(1):80-8.

32. Chandramouli V, Kailasapathy K, Peiris P, Jones M. An improved method of microencapsulation and its evaluation to protect Lactobacillus spp. in simulated gastric conditions. Journal of microbiological methods. 2004 ; 56(1):27-35.

33. Krasaekoopt W, Bhandari B, Deeth H. Evaluation of encapsulation techniques of probiotics for yoghurt. International Dairy Journal. 2003; 13(1):3-13.

34. Rodrigues D, Sousa S, Rocha-Santos T, Silva JP, Lobo JS, Costa P, Amaral MH, Pintado MM, Gomes AM, Malcata FX, Freitas AC. Influence of L-cysteine, oxygen and relative humidity upon survival throughout storage of probiotic bacteria in whey protein-based microcapsules. International Dairy Journal. 2011; 21(11):86976. 